\title{
Deprem Riski Yüksek Bölgelerde İç Mekân Düzenlemelerinin İncelenmesi (Tosya Örneği) *Mehmet KARAMANOĞLU ${ }^{1}$, Göksel ULAY ${ }^{2}$
}

\author{
${ }^{1}$ Kastamonu Üniversitesi, Tosya Meslek Yüksekokulu, Malzeme ve Malzeme İşleme \\ Teknolojileri Bölümü, Mobilya Dekorasyon Programı, Tosya 37300 Kastamonu/Türkiye \\ ${ }^{2}$ Yüzüncü Y11 Üniversitesi, Van Meslek Yüksekokulu, Malzeme ve Malzeme İşleme \\ Teknolojileri Bölümü, Mobilya Dekorasyon Programı, 65080 Van/Türkiye \\ *Sorumlu yazar: mkaramanoglu@kastamonu.edu.tr
}

Özet: Türkiye'nin deprem kuşağında yer alan bir ülke olarak sınırları içerisinde birçok deprem meydana gelmiş̧ir. Yakın gelecekte de farklı bölgelerinde benzer şiddetlerde depremlerin olabileceği konunun uzmanları tarafından açıklanmaktadır. Kuzey Anadolu Fay Hattı üzerinde bulunan Kastamonu İli Tosya İlçesi I. Derece deprem bölgesinde yer aldığından geçmişte birçok deprem yaşamıştır. Yapılan araştırmalarda uygun olmayan bina yapısı ve iç mekân düzenlemeleri gibi önlenebilir birçok faktörün can ve mal kaybına neden olduğu bilinmektedir. Araştırmada Kastamonu İli Tosya İlçesi sakinlerine yönelik bir anket uygulanmıştır ve mobilya kullanım alışkanlıkları depreme karş̧ alınacak tedbirler çerçevesinde incelenmiştir. Sonuç olarak deprem bölgesi konutlarında yaşayanların iç mekân düzenlemelerindeki farkındalık düzeyleri ortaya çıkartılmıştır ve sorunlara yönelik önerilere yer verilmiştir.

Anahtar Kelimeler: İç mekân, Mobilya, Dekorasyon, Deprem.

\section{Investigation of Interior Settings on High Earthquake Risk Areas \\ (Case study of Tosya)}

Abstract:As a country which takes part in the earthquake zone, Turkey has experienced so many earthquakes within its borders. Experts have made it clear that Turkey is likely to have similar earthquakes in different zones in near future. Since Tosya; Kastamonu is located on North Anatolian Fault Line and known as the first degree seismic zone, the city experienced many earthquakes in the past. According to the researches, avoidable many factors such as inappropriate building structures and interior designs, all led to the loss of life and property. A questionnaire has been applied to the people who live in Tosya, Kastamonu during the research and their furniture use habits have been taken in to consideration in terms of actions to be taken against earthquakes. Consequently awareness level of the people about the interior design of their houses which are located in the seismic zone has been brought out and some solutions and suggestions for the problems have been introduced.

Key words: Interior, furniture, decoration, earthquake.

\section{Giriş}

Öncelikle deprem kavramının tanımını yapmak gerekirse yer kabuğundaki kırılmalar nedeniyle ani olarak ortaya çıkan titreşimlerin dalgalar halinde yayılarak geçtikleri ortamları sarsma olayına deprem denir (İşçi, 2008). Türkiye Deprem Haritası'na göre (Şekil 1), $\% 95$ 'i deprem riski taşımakta olan Ülkemizin $\% 92$ 'si deprem bölgeleri içerisinde, büyük sanayi merkezlerinin \%98'i ve barajlarımızın \%93'ü deprem bölgesinde bulunmaktadır. Türkiye'de, son 58 y1l içerisinde depremlerden, 58.202 kişi hayatını kaybetmiş, 122.096 kişi yaralanmış ve yaklaşık olarak 411.465 bina yıkılmış veya ağır hasar görmüştür (Ulay, 2013). Yakın geçmişte ülkemizin farklı şehirlerinde yaşanan ve büyük hasarlara ve can kaybına neden olan depremler hatırlanacak olursa ki bunlar; 1992 Erzincan,1995 Afyon- Dinar, Adana-Ceyhan 1998, 1999 Kocaeli, 1999 Düzce, 2002 Afyon-Sultandağı, 2003 Tunceli-Pülümür, 2003 Bingöl, 2005 İzmir, 2010 ElazığKarakoçan, 2011 Kütahya Simav, 2011 Van ve Van-Edremit ilçesinde yaşanan depremlerdir (URL-2, 2016). Dolayisıyla Türkiye'nin farklı bölgelerinde yaşanan ve gelecekte de benzer şiddette deprem yaşanma ihtimali yüksek gözükmektedir.

Çalışmamızın konusunu oluşturan Kastamonu ilive Tosya ilçesinin deprem tarihine baktığımızda aletsel döneme ait (1900 - 2000 yılları arasinda) 9 tane hasar yapan deprem meydana gelmiştir. Bu depremler 
tarih sırasına göre; 09 Mart 1902 Çankırı Depremi (maksimum şiddeti Io:IX), 25 Haziran 1910 Tosya (Kastamonu) Depremi (maksimum şiddeti Io:VII, magnitüdü Ms:6.1), 9 Haziran 1919 Almus (Tokat) Depremi (Io:VIII, Ms:5.9), 21 Kasim 1942 Osmancık Depremi (Ms:5.5), 2 Aralık 1942 Çorum Depremi (Io:VIII, Ms:5.9), 11 Aralık 1942 Çorum Depremi (Io:VI, Ms:5.9), 26 Kasım 1943 Tosya - Ladik Depremi (Io:X, Ms:7.2).

Kastamonu merkez ilçesi bu depremden VIII şiddetinde etkilenmiştir. Bu deprem de Doğuda Taşova'dan, batıda Ilgaz'a kadar uzanan ve takriben $45000 \mathrm{~km}^{2}$, yi kapsayan bir bölge içinde kasaba ve köylerdeki evlerin \%75'inin tümüyle yıkıldığı ya da ağır hasara uğradığı, sayısı tam olarak belirlenememiş olmakla birlikte 4000 kişinin öldüğü, 5000 kişinin de yaralandığ 1 bildirilmiş̧ir (Dirik, 2004). Bir deprem kuşağı üzerinde yer alan ülkemizde yaşanan her sarsıntıda binalar öldürmese bile içindeki eşyalar çıkan paniğin de etkisi ile insanlara zarar verdiği bildirilmiştir (Demirarslan, 2005).

Mühendislik teknolojisinin ve içyapı tasarımlarının gelişmesi sayesinde yapılardaki deprem hasarlarının azaltıldı $\breve{~} 1$ belirtilmiştir fakat, deprem anındaki sallantı anında yerlerinden çıkabilen ya da devrilebilen mobilya veya diğer donatıların insanlar için tehlike oluşturabildiği bildirilmiştir (Winkler ve Meguro, 1996).

Deprem gibi sarsintılardan dolayı bazı eşyaların dengelerinin bozulması sonucunda devrilmesi ile mekanlardan çok insanlara zarar verebildiği vurgulamıştır (Aytöre, 2005). Yaşanan depremlerden edinilen deneyimlerin iç mekan örgütlenme biçimi ve geometrisi, duvar-tavan ve döşeme bitiş yüzeyi, aydınlatma elemanları vb. aksesuarların güvenli mekanlar oluşturulmasında çok önemli unsurlar olduğunu bildirilmiştir (Demirbaş, 2008). Mekan ve donatı ilişkisi deprem faktörü ile birlikte düşünüldüğünde bu çerçevedeki alınabilecek önlemler ile ilgili literatür incelendiğinde; büyük bir deprem yaşayan Meksika'nın başkentinde yapılan araştırmada, insanların ev içindeki mobilyaları kaçış yollarını engellemeyecek şekilde yerleştirdiklerini ancak, doğru şekilde yerleştirilen mobilyaların sabitlemeden kullanıldığını tespit edilmiştir. (Navarro, 1997). Yeni Zelanda'nın başkentinde yapılan bir araştırmada, ev eşyalarının \%90'nına yakınının sabitlenmediği bildirilmiştir. Yüksekliği fazla olan mobilyaları, duvar ve mobilyalar zarar göreceğinden dolayı sabitlemediklerini tespit etmişlerdir (Charleson ve ark., 2003). Türkiye'deki Simav ve Düzce'de yaşayan üniversite personellerinden oluşan 79 kişiye yönelik yapılan araştırmada, kullanıcıların çoğunun konut içindeki mobilyaların doğru yerleştirilmesi, sabitlenmesi vb. önlemlerin alınmadığı tespit edilmiştir (Uzun ve ark., 2015). Ulay ve Bekiroğlu (2016), araştırmaya dâhil olan bireylerin yaklaşık yarısının deprem sirasında mobilyalarının sallanıp yerlerinden oynadığını ve bir kısmının ise mobilyaların devrildiğini, kapaklarının açılarak eşyaların döküldüğünü tespit etmişlerdir. Deprem yaşamış bireylerin tedbir alma durumları incelendiğinde yeterli düzeyde olmadığını ve az da olsa bazı önlemlerin alınmış olduğunu bildirmişlerdir.

Kuzey Anadolu Fay Hattı üzerinde ve birinci derece deprem bölgesi içerisinde bulunan Kastamonu İli Tosya İlçesi ve benzer durumda birçok il ve ilçe için konut, barınma, iç mekân donatıları ve deprem kavramlarının bir çerçevede ele alınarak incelenmesi gerekmektedir. Yapılmış teknik ve bilimsel çalışmalar doğrultusunda uzman desteği ile konut, iş yeri, okul vb. bütün iç mekânlarda donatılarla ilgili yapılacak bütün düzenlemelerde deprem felaketi sonucu eşya ve donatının neden olacağı yaralanma ve ölüm oranının azaltılması ve bu yörelerde yaşayan insanların bilinçlendirilmesi önem arz etmektedir. 


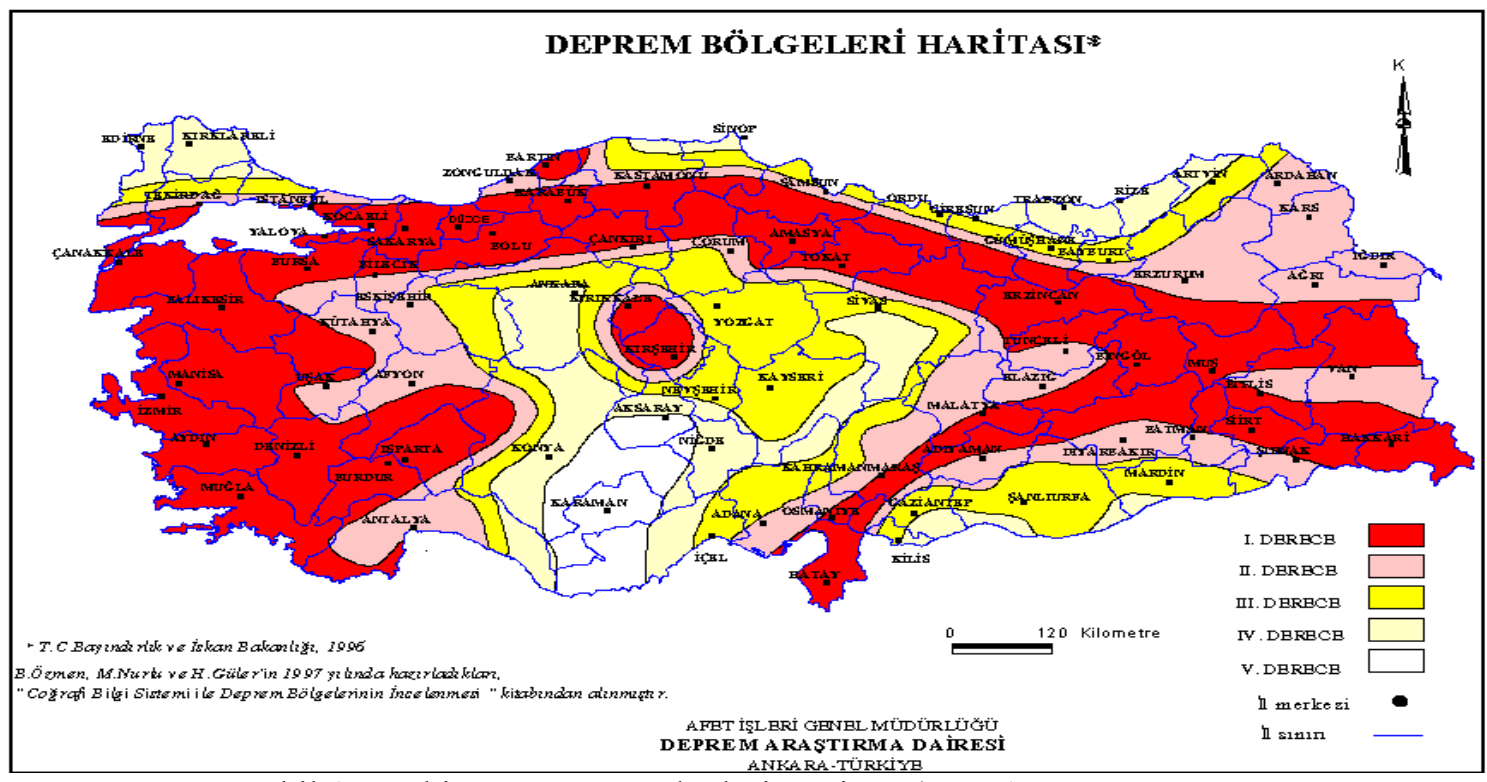

Şekil 1. Türkiye Deprem Bölgeleri Haritası (URL1-AFAD, 2013)

\section{Materyal ve Yöntem}

$\mathrm{Bu}$ araştırma kapsamında Kastamonu İli Tosya İlçesinde olası bir depreme karşı yaşamın büyük bölümünün sürdürüldüğü konutların iç mekân düzenlemeleri incelenmiştir. Anket yöntemi uygulanırken aşağıda verilen hesaplama yöntemi kullanılmıştır. Tosya yerel yönetim kayıtları incelenerek ilçe merkezinde yaklaşık 6000 konut olduğu tespit edilmiştir. Bu tespite göre; aşağıda açıklanan yöntem ile $\% 95$ güven düzeyinde $\% 5$ örnekleme hatas1 kabullenilerek en az 75 konuta anket yapılmasına karar verilmiştir.

$$
n=\frac{Z^{2} N P Q}{N D^{2}+Z^{2} P Q}
$$

$$
n=\frac{1.96^{2} \times 6000 \times 0.95 \times 0.05}{6000 \times 0.05^{2}+1.96^{2} \times 0.95 \times 0.05}=72,06=75
$$

Burada;

$\mathrm{n}=$ Örnek Büyüklüğü

$\mathrm{Z}=$ Güven Katsayısı(\%95 için 1.96 alınmıştır)

$\mathrm{P}=$ Ölçmek istediğimiz özelliğin kütlede bulunma ihtimali (\%95 olarak alınmıştır)

$\mathrm{Q}=1-\mathrm{P}$

N=Ana kütle büyüklüğüu(6000 olarak alınmıștır)
$\mathrm{D}=$ Kabul edilen örnekleme hatası(Çalışma için \%5'lik örnekleme hatası öngörülmüsşür)

Hangi konutlara anket yapılacağı, çalışma amaçları doğrultusunda hedef kitleyi oluşturan konutlara öncelik verecek şekilde ilçe merkezi sınırları içerisinde bulunan konutlardan rastlantısal örnekleme yöntemi kullanılarak belirlenmiștir. Anketler konut sahipleri ile yüz yüze yapılmış ve anket yapılmasına izin veren konutlarda yapılmıştır. Aynı zamanda anketteki kapalı uçlu sorular için sözlü mülakatta yapılmıştır. Anketlerden elde edilen verilerden kapalı uçlu soruların cevabını değiştirmeden, açık uçlu soruların ki ise anlamlı kavramlar haline getirilerek SPSS istatistik programı kullanılarak değerlendirilmiştir.

Deprem bölgesi konutlarında yaşayanların iç mekân düzenlemelerindeki farkındalık düzeyleri ortaya çıkartılmıştır ve sorunlara yönelik önerilere yer verilmiştir.

\section{Bulgular ve Tartışma}

Katılımcıların demografik özelliklerine ait veriler Tablo 1'de verilmiştir. 
Tablo1. Katılımcıların demografik özellikleri

\begin{tabular}{|c|c|c|c|}
\hline \multicolumn{2}{|c|}{ Demografik Özellikler } & \multirow{2}{*}{$\begin{array}{c}\mathbf{F} \\
46\end{array}$} & \multirow{2}{*}{$\begin{array}{l}\mathbf{f ( \% )} \\
61.3\end{array}$} \\
\hline \multirow{3}{*}{ Cinsiyet } & Erkek & & \\
\hline & Bayan & 29 & 38.7 \\
\hline & & $\Sigma 75$ & 100 \\
\hline \multirow{5}{*}{$\begin{array}{l}\text { Medeni } \\
\text { Durumu }\end{array}$} & Evli & 45 & 60 \\
\hline & Bekâr & 22 & 29.4 \\
\hline & Boşanmış & 4 & 5.3 \\
\hline & Dul & 4 & 5.3 \\
\hline & & $\Sigma 75$ & 100 \\
\hline \multirow{6}{*}{$\begin{array}{c}\text { Eğitim } \\
\text { Durumu }\end{array}$} & İ́lkokul & 9 & 12 \\
\hline & Ortaokul & 8 & 10.6 \\
\hline & Lise & 36 & 48 \\
\hline & Ön Lisans & 13 & 17.4 \\
\hline & Lisans & 9 & 12 \\
\hline & & $\Sigma 75$ & 100 \\
\hline \multirow{10}{*}{ Mesleği } & Memur & 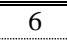 & 8 \\
\hline & Ev Hanımı & 24 & 32 \\
\hline & İş̧̧i & 7 & 9.3 \\
\hline & Serbest Meslek & 8 & 10.7 \\
\hline & Esnaf & 7 & 9.3 \\
\hline & Emekli & 3 & 4 \\
\hline & Çalışmiyor & 3 & 4 \\
\hline & Ögrenci & 14 & 18.7 \\
\hline & Diğer & 3 & 4 \\
\hline & & $\Sigma 75$ & 100 \\
\hline
\end{tabular}

Anket sonuçlarına göre; katılımcıların \%90'1n üzerinde zorunlu deprem sigortasına (DASK) sahip olmadıkları görülmüştür. Ekim 2016 itibari ile Kastamonu ili genelindeki 73.710 konutun 26.673 'ü yani \%36.2'si sigortalıdır (URL-3). Literatürde Ulay ve Bekiroğlu (2016) Van ilinde 2011 yılında yaşanan depremde bireylerin \%86,4'nün deprem sigortası bulunmadığı tespit etmiştir. Farklı bölgelerde yapılmış olmasına rağmen araştırmaların sonuçları düşük deprem sigortalılık oranları bağlamında benzerlik göstermektedir.

Ülkede yaşanan depremler ve diğer nedenlerden kaynaklı DASK yaptıranların oranı son y1llarda geçtikçe artmaktadır. Türkiye genelinde zorunlu deprem sigortas1 yaptırma oran 2000 yılında \%4 iken, 2014 y1lında \%36.5 (URL-4, 2016) ve Ekim 2016 itibari ile \%42.40 ile 7.4 milyon (URL-3, 2016) poliçeye ulaşmıştır.

Olas1 bir deprem felaketinin neden olabileceği kayıplara ve felaket yaşanmadan önce depreme karş1 alınabilecek önlemlere dair katılımciların \%65'nin herhangi bir bilgiye sahip olmadığı tespit edilmiştir. Literatürdeki Ulay ve Bekiroğlu (2016)'nun Van ilinde yapmış olduğu araştırmada \%53.4'nün bilgisi olması olmadığı tespit edilmiştir. $\mathrm{Bu}$ sonuçlar göstermektedir ki neredeyse tamamına yakını deprem kuşağında yer alan Türkiye de yaşayan, bireylerin deprem ile yaşamak ve gerekli önlemleri almak için bilgi düzeyleri ve hazırlıkları istenen seviyede değildir.

Kat1lımc1ların \%85'nin olası bir depreme karşı almış olduğu önlem veya önlemlerin olmadığ1 görülmüştür. Yeni bir eve taşınmak önlem olarak görülmektedir.

Alınması gereken önlemler hakkında katılımcıların \%62'nin bilgi sahibi olmadığı, bunun yanı sıra ekonomik nedenlerle, felaketin boyutları hakkında bilgisizlik nedenleri ile önlem almadıkları tespit edilmiştir.

Katılımc1ların \% 70'nin apartman dairesi ve çok katl1, \%30'nun müstakil ve az katlı konutlarda yaşadığı, bu konutların \%40'nın 3oda + mutfak + banyo + wc, \%19'unun 2oda + mutfak + banyo + wc, \%12'sinin 4oda + mutfak + banyo + wc, \%1'nin loda + mutfak + banyo + wc ve \%3'nün diğer konut tiplerinde ikamet ettiği ve olası bir deprem sirasında bu alanlarda bulunacağ görülmektedir.

Muhtemel bir deprem felaketi sirasinda ilk tepki olarak katılımcıların \%34.7'si kaçarım, $\% 32$ 'si olduğum yerde kalırım, \%33.3'ü ise 
güvenli bir alan bulup sığınmaya çalışırım tepkilerini göstermiştir. Deprem anında bilinçli bir kişinin ilk tepkisinin yakınındaki güvenli bir yere geçmesi gerektiği düşünüldüğünde kaçarım veya olduğum yerde kalırım diyen \%66.7'si bu konuda bilgilendirilmelidir. Literatürde Davis (2003), Kaliforniya'daki eğitim kurumlarında herhangi bir deprem anında korunmak ve zarar görmeden depremi atlatmak için kılavuz ve kontrol listesi hazırlanmıştır. Ulay (2013), Meslek Yüksekokul öğrencilerini deprem konusunda bilinçlendirmek için dersliklere çııış merdivenlerinin girişine deprem faktörüne karşı mobilyalardaki önlemleri ile ilgili görselleri (Şekil.2-5) ve bilgileri içeren bir posteri öğrencilerin her gün görebileceği bir noktada sergilemektedir.

Deprem sirasında bulunduğunuz yerdeki eşyalarda ne tür bir hareket meydana gelebilir sorusuna katılımcıların \%62'si eşya sallantı ile devrilebilir, \%34'ü eşya sallantı ile yerinden oynar, $\% 22$ 'si eşya depremde yerden yükselir ve içindekiler dışarılara savrulur, \%50'si eşya deprem esnasında kaçış yolumu kapatır/engeller şeklinde fikir beyan etmiştir. Araştırma da bu sonuçlar tespit edilmiş olmasına rağmen katılımcıların çoğu bu durumlara karşı tedbir almaması düşündürücüdür. $\mathrm{Bu}$ davranış biçiminin depremlerin sebebini ve sonuçlarının batıl inanç kaynaklı nedenlere (kıyamet alameti, nazar, günahlar, kader vb.) dayandırma alışkanlığından kaynaklandığı düşünülmektedir.

Olası bir depremde katılımc1ların \%40'1 bulunabilecekleri alanlardan kaçışlarını engelleyecek eşyaların bulunduğunu beyan etmiştir. Literatürde İş̧̧i (2008)'nin yaptığ 1 çalışmada binalar kadar mobilyalarında depremde öldürücü etkileri olduğunun göz ard1 edilmemesini önermiştir. Uzun ve ark.(2015) kullanıcıların \%76.9'nun yatak odasındaki mobilyalarını duvara sabitlemedikleri ve \%65.8'nin yatak odalarındaki mobilyalarını deprem veya sarsıntı anında yaralanmalara veya ölümlere yol açmayacak şekilde güvenli olmadığını düşündüklerini tespit etmişlerdir. Dolayısıyla literatürdeki sonuçlarla birlikte düşünüldüğünde farklı deprem bölgelerinde yaşayan ve hatta geçmişte yıkıcı depremleri yaşamış olsalar bile yaşadıkları mekânlar 'da yeterli düzeyde önlemleri alıp deprem ile yaşamaya hazır oldukları söylenemez.

Katılımcılar olası bir depremde yüksek oranda duvar paneli, mutfak dolab1, buzdolab1, TV seti, gardırop, komodin, şifonyer, avize/lamba, yemek masası, kitaplık, vitrin, pano/tablo, gümüşlük vb. eşyalardan zarar görebilecekleri ortaya çımıştır. Aytöre (2005), bu tip eşyaların deprem güvenliğine uygun özel bağlama elamanları ile doğru bir şekilde sabitlenmesini önermiştir.

Eşyaların zarar verme derecesini katılımcıların \%42'si ağır yaralanma, \%17'si ölüm, \%12'si kaçışı engelleme, \%4'ü ise hafif yaralanma ile sonuçlanabileceğini bildirmişlerdir. Ayrılmış ve ark. (2015), Kağıt petekli levhalardan panel, kapı üretimi, mobilya ve duvar panelleri gibi ürünler hali hazırda üretilmekte olan bu tür ürünlerin deprem bölgelerindeki mekan dekorasyonlarında değerlendirilebileceğini bildirmiştir. Eşyanın zarar derecesini azaltmak için literatürde, mobilyaların güvenli kullanımlarına uygun imal edilmesi için hafif ahşap, ahşap kompozit levhalar (Güler ve Ulay, 2009;2010) vb. malzeme kullanımları önerilmektedir (Ulay, 2013; Ulay ve Bekiroğlu, 2013;2016; Ayrılmış ve ark., 2015). Depreme yönelik olarak eşyalarda veya yapılan iç mekân düzenlemelerinde kat1lımciların \%83'ünün herhangi bir uzmandan yardım almadığı ve sağlam yapılan binalarda eşyalar için özel tedbirlerin alınmadığ 1 tespit edilmiştir. Uzun ve ark. (2016) Düzce ve Simav gibi deprem yaşama ihtimali yüksek bölgelerde yaptıkları çalışmada benzer sonuçlar çıkmıştır. Bu sonuçlar literatürde yer alan ve dünyanın farklı coğrafyalarında yapılmış çalışmaların Navarro (1997), Charleson ve ark. (2003), sonuçları ile de uyumludur.

Katılımcıların \%76'nın alınan eşyalarda depreme dayanıklılık açısından özellikler aramadığı belirlenmiştir. Literatürde Ulay (2016), toplumun deprem konusunda ve "güvenli mobilya" kavramları hakkında eğitim, sosyal projeler, kongre, sempozyum, 
film, sinema, TV reklamları vb. etkinlikler yoluyla ile bilinçlendirilmesini önermiştir. Ayrıca Ulay, mobilya satan mağazaların müşterilerin evlerinde montaj sırasında mobilyaların duvar veya tavana sabitleme hizmeti vermesi gerektiğini de önermiştir.

Depreme yönelik duvara asılan raf/tablo/süs eşyası vb. elemanlarda, mobilyalarda aydınlatma elemanlarında katılımcıların olası bir depreme karşı değişiklik yapmadığ 1 tespit edilmiştir.

Aytöre (2005), Ertürk (2003) ve Ulay (2013) olası bir depreme karşı eşyalarda Şekil 2-3-4-5'teki gibi düzenlemeler önermektedir.
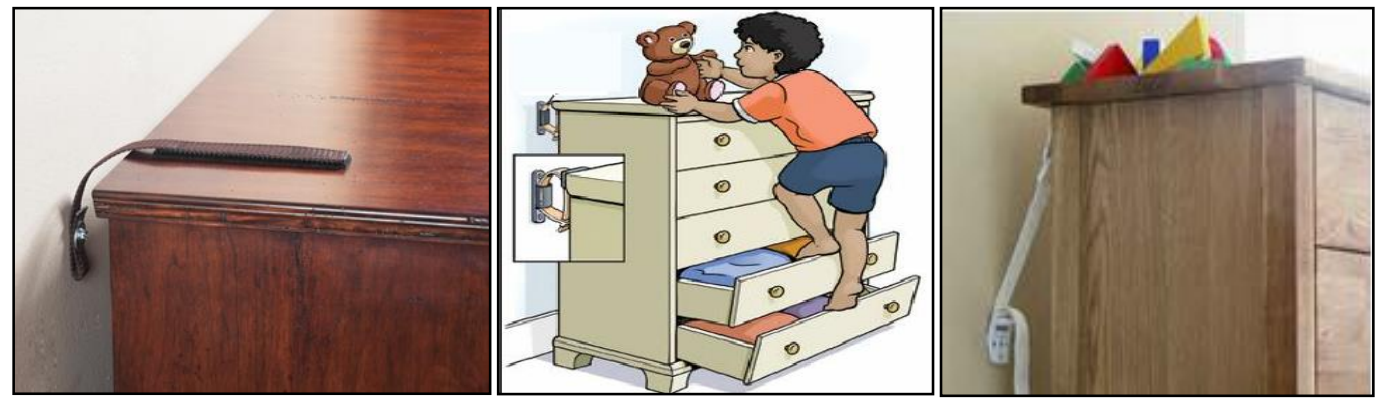

Şekil 2. Gardrop ve Şifonyer Duvar Bağlantı Uygulamaları (Ulay, 2013;URL-5, 2016)
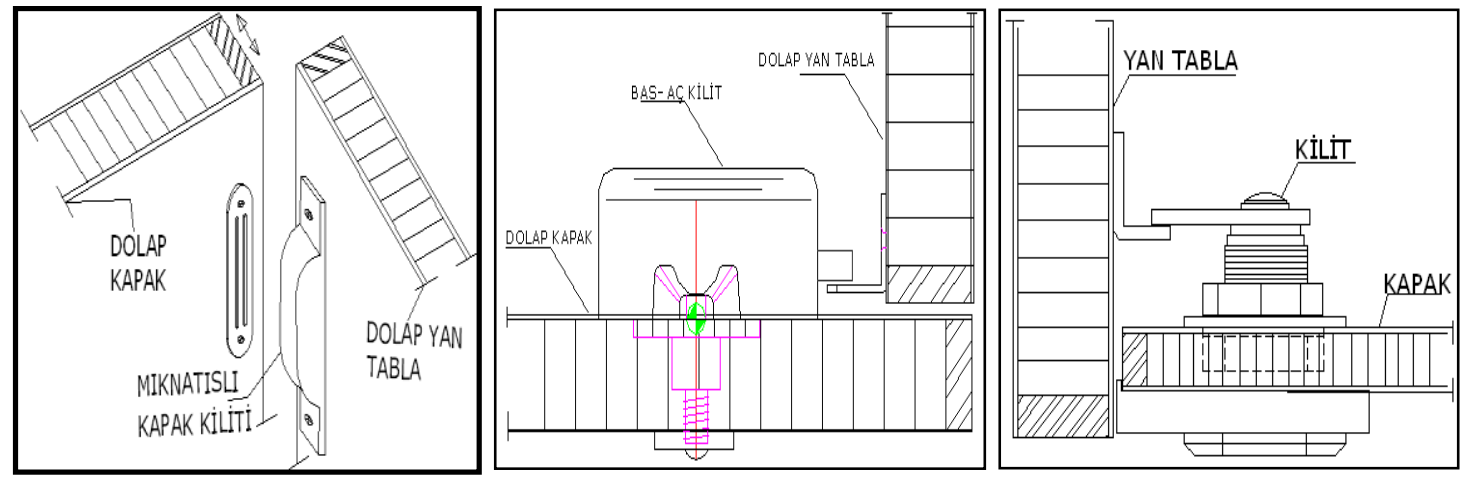

Şekil 3. Kapak Sabitleme ve Kapak Kilit Uygulamaları (Ulay, 2013)
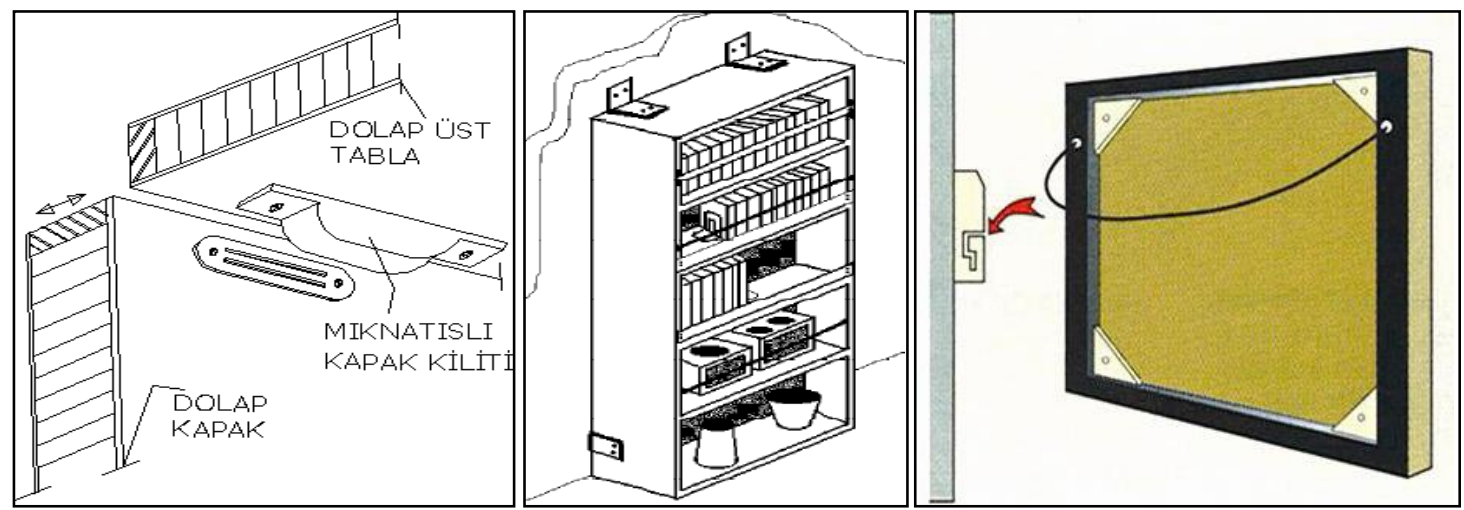

Şekil 4. Dolap ve Kapak Sabitleme Uygulama (Ulay, 2013) Şekil 5. Ayna, Saati ve Tablo Bağlantı Uygulaması 


\section{Sonuç ve Öneriler}

Mobilya, eşya ve dekorasyon donatılarının olası bir depreme veya sarsıntıya karşı ve günlük kullanım esnasında meydana gelebilecek tehlikeleri ve etkilerini en aza indirgemek için uygun bağlantı elamanı ve konstrüksiyon vb. teknikler ile (şekil 1-4) sabitlenmesi (Davis, 2003;Aytöre, 2005; Ulay, 2013; URL-5) önem arz etmektedir. Ayrıca bu uygulamalar özellikle çocukların için günlük yaşam içerisinde korunmasını sağlayacaktır.

Deprem, deprem felaketinin doğuracağ 1 etkiler ve bu etkilere iç mekân donatılarının etkisinin neler olduğu ülkemizde birinci derece deprem bölgelerinde yaşayan insanların acı bir tecrübesidir. Fakat gerek yapılaşma, gerek eşya kullanımında muhtemel bir depreme ve etkilerine karş1 önlem almama yapılan bilimsel ve teknik çalışmaların üzücü sonucudur. Bu sonuçların değişebilmesi için resmi ve sivil toplum kuruluşlarının ve üniversitelerin etkileşimi ile uzman destekli eğitimlerin yaygınlaştırılması önerilmektedir. Aynı zamanda yapılaşmada olduğu gibi iç mekân uygulamalarının yasal mevzuatlarla zorunlu hale getirilmesi önem arz etmektedir.

Deprem sigortas1 yaptırilma oranlar1 bağlamında düşünüldüğünde Tosya ilçesinde yapılan bu araştırma sonuçlarına göre yaklaşık \%10 olan DASK yaptırma oranı, Kastamonu ili genelindeki sigortalılık oranı \%36,2 (URL-3) ortalamasının altında kaldığ görülmektedir. Türkiye genelindeki DASK sigortas1 yaptıranların oran1 \%42,40 (URL-3) olduğu düşünülürse ülke ortalamasının da gerisindedir. 1. derece deprem bölgesi olduğu bilinen Tosya ilçesi için olası bir hasarlı deprem felaketi sonrasi ekonomik sıkıntılarında kaçınılmaz olduğu göz ardı edilmemelidir. Ayrıca Tosya özelinde yapılacak yeni araştırmalar ile sigortalılık oranlarının düşük olmasının nedenleri ortaya çıkarılabilir.

Son y1llarda kentsel dönüşüm projelerinin yürütüldüğü ülkemizde bina, iç mekan düzenlemeleri ve mobilya - eşya tasarımlarının modüler sisteme yönelik tasarlanmasi, üretilmesi ve düzenlenmesi önem arz edecektir. Eşya bağlantılarının daha sağlıklı yapılabilmesi ve ürün ağıllıklarını azaltmak, hafif ve daha esnek hale getirmek için kompozit malzemelerin kullanılması (Ayrılmış ve ark., 2015; Ulay ve Güler, 2010;Ulay ve Bekiroğlu, 2016) önerilmektedir. Kompozit malzeme ve uygun bağlantı elamanı doğru aksesuar şeçimimodüler sistem etkileşimi olası bir depremin olumsuz etkilerini en aza indirgeyebilecektir.

Sonuç olarak bu çalışmanın sonuçları Tosya ilçe merkezindeki bireyler özelinde olup genelleme yapılması uygun olmayabilir. Literatürle ilişkilendirilebilen benzer sonuçlar çalışmada vurgulanmıştır. Türkiye genelinde yapılabilecek daha büyük örneklem gurubuna yönelik araștırma, ülke genelindeki insanların deprem faktörüne karșı iç mekan düzenleme ve kullanım durumları ortaya çıkarılarak bu konuda toplumsal bilinç oluşturulmalıdır. Deprem kuşağında yer alan ülkenin vatandaşları olarak tüm bireyler "deprem ile yaşamak" kavramlarının içini doldurarak, yaşam alanlarına yansıtabilmelidirler. $\mathrm{Bu}$ süreçte sivil toplum kuruluşlarına, medyaya ve resmi kurumlar ile eğitim kurumlarına özellikle çok iş düşmektedir.

\section{Kaynaklar}

Aytöre, S., O., (2005). Depolama ve üretim bi çimleri açılarından seri üretilen mobilyaların deprem karşısında insan üzerindeki etkileri. Deprem Sempz., Kocaeli.

Demirarslan, D., (2005). Türk ve Japon konut iç mekanlarında depremsellik açısından konut ve eşya kullanım alışkanlıklarının irdelenmesi. Deprem Sempz., Kocaeli.

Dirik, K., (2004). Kastamonu İli ve Civarının Depremselliği, KASYÖ-DER Kültür Dergisi, 2, 17, 19-21.

Ertürk, F., (2003). 17 Ağustos 1999 İzmit depreminde evi zarar gören ailelerin geçici ve kalıcı konutlardaki yaşamlarının bina-mobilya açısından incelenmesi ve sonuçları. Kocaeli Üniversitesi., İç Mimarlık, Y.Lisans Tezi.

Güler, C., Ulay, G., (2010). Köpüklü Kompozit (Sandviç) Levhaların Bazı Teknolojik Özellikleri. SDÜ, Turkish Journal of Forestry| Türkiye Ormanc1lık Dergisi 2 (2010): 88-96.

İşçi, C., (2008). Deprem nedir ve nasıl korunuruz?. Journal of Yasar University, 3(9): 959-983.

URL1,2013.http://www.deprem.gov.tr/sarbis/Sha red/DepremHaritalari.aspx Son Erişim: 08/08/2013.

Ulay, G., (2013). Depreme Karşı İç Mekan Donatılarındaki Çözümlemeler. PÜ, II. Ulusal Mobilya Kongresi, 618-627, Denizli. 
Güler C. ve Ulay G., (2009). Petekli (honeycomb) kompozit levhalar. Mobilya Dekorasyon Dergisi, 90, ss.78-92.

Uzun, O., Perçin, O., Küreli, İ., (2015). Kullanıcıların Deprem Hazırlıklarının İç Mekân ve Mobilyalarında Belirlenmesi (Simav ve Düzce örneği), Kastamonu Üniversitesi Orman Fakültesi Dergisi, 15(2),ss.183-196.

Ulay, G. ve Bekiroğlu M. S., (2016). Yüzüncü Y1l Üniversitesi Fen Bilimleri Enstitüsü Dergisi/ Journal of The Institute of Natural \& Applied Sciences, 21 (1):43-54,

Ulay, G., (2016). Erzincan Depremlerinin Sonuçları ve Dekorasyon Üzerine Etkisi, Uluslararası Erzincan Sempozyumu, 28 Eylül-1 Ekim 21016, Bildiriler kitab1,. (ss: , basim aşamasında), Erzincan, Türkiye.

Ulay, G., And Bekiroğlu M.S., (2013). Van Earthquake and its impact on using the indoor furniture, International Van Earthquake Symposium, 23-27 October 2013, Abstracts book, pp:222, Van, Turkey.

Karamanoğlu M. S. And Ulay G., (2013). The Study of Interior Arrangements In High Risk Earthquake Zones (The example of Tosya), International Van Earthquake Symposium, 23-27 October 2013, Abstracts book, pp:215, Van, Turkey.

Ayrılmış, N., Ulay, G., Bağlı F.E., Özkan, İ., (2015). Ahşap Sandviç Kompozit Levhaların Yapıs1 ve Mobilya Endüstrisinde Kullanımı, Kastamonu Üniversitesi, Orman Fakültesi Dergisi, 15 (1), ss.37-48
Charleson, A.W.,Cook, B., Bowering, G. 2003. Assessing and increasing the Level of earthquake preparedness in Wellington homes. Pasific Conference on Earthquake Engineering, 137-144

Navarro, M. E. L. 1997. Earthquake precautionary measures in post-disaster housing with reference to Mexico City. Master thesis, Mc Gill University School of Architecture, 62 s. Mexico

Davis, G. 2003. Guide and checklist for nonstructural earthquake hazards in California schools, 1-49 s, California Government, California.

Winkler, T.,Meguro, K. 1996. Response of interior rigid body assemblies to dynamic excitation. Eleventh World Conference on Earthquake Engineering (1996), 581

URL_2, 2016, Türkiye'deki depremler listesi, https://tr.wikipedia.org/wiki/T\%C3\%BCrkiye\%2 7deki_depremler_listesi Son Erişim: 08/10/2016.

URL 3, 2016, Bölge ve il bazında DASK sigortalılık oranları, http://dask.gov.tr/zorunludeprem-sigortasi-istatistikler-2.htmlb , Son Erişim: 08/10/2016.

URL_4, 2016, Deprem Sigortası Sahibi Olanların Oranı 14 yılda 9 Kat Arttı! , https://www.sigortam.net/dask-sigortasi/depremsigortasi-yaptiranlarin-orani-artti Son Erişim: 08/10/2016.

URL_5, 2016, Deprem Güvenlik Malzemeleri, http://www.parkzon.com.tr/deprem/default.aspx Son Erişim: 09/10/2016. 